\title{
Antioxidant abilities and physiological properties of dried Haw extracts prepared using different drying methods
}

\author{
San $\mathrm{Nam}^{1}$, Yu-ri Kwon ${ }^{1,3}$, Hun-Sik Chung ${ }^{2}$, Kwang-Sup Youn ${ }^{1,3 *}$ \\ ${ }^{1}$ Department of Food Science and Technology, Catholic University of Daegu, Gyeongsan 38430, Korea \\ ${ }^{2}$ Department of Food Science and Technology, Pusan National University, Miryang 50463, Korea \\ ${ }^{3}$ Institute of Food Science and Technology, Catholic University of Daegu, Gyeongsan 38430, Korea
}

\section{건조 방법에 따른 산사과 추출물의 항산화 및 생리활성}

\author{
남산 $^{1} \cdot$ 권유리 ${ }^{1,3} \cdot$ 정헌식 ${ }^{2} \cdot$ 윤광섭 $1,3 *$ \\ ${ }^{1}$ 대구가톨릭대학교 식품공학전공, ${ }^{2}$ 부산대학교 식품공학과, \\ ${ }^{3}$ 대구가톨릭대학교 식품과학연구소
}

\begin{abstract}
This study was performed to determine the effects of drying methods (HD, hot air drying; FD, freeze-drying) on the antioxidant and physiological abilities of Haw (Crataegus pinnatifida Bunge). Powder color values of dried Haw, $L$ and $b$, were higher for HD, while the chroma values were higher for FD. The total polyphenol, and flavonoid contents of HD Haw and FD Haw were found to be $9.29 \pm 0.50 \mathrm{mg} \mathrm{GAE} / \mathrm{mL}$ and $15.48 \pm 0.38 \mathrm{mg} \mathrm{GAE} / \mathrm{mL}$, and $9.41 \pm 0.26 \mathrm{mg} R H E / \mathrm{mL}$ and $26.46 \pm 0.34 \mathrm{mg} \mathrm{RHE} / \mathrm{mL}$, respectively. DPPH radical scavenging abilities at $100 \mathrm{mg} / \mathrm{mL}$ concentration were higher for FD $(\mathbf{6 4 . 9 0 \% )}$ ) than $\mathrm{HD}(\mathbf{2 8 . 6 6 \%})$, as were the reducing power, ABTS radical scavenging ability, and nitrite scavenging ability. However, the HMG-COA reductase of $\mathrm{HD}$ (74.67\%) was higher than that of FD (72.10\%). The $a$-glucosidase inhibitory abilities of $\mathrm{HD}$ and FD at a concentration of $0.1 \mathrm{mg} / \mathrm{mL}$ were $24.69 \%$ and $97.38 \%$, respectively. These results indicate that Haw is a potential functional material and that freeze-drying Haw is better than hot air drying.
\end{abstract}

Key words : Haw (Crataegus pinnatifida Bunge), Drying method, Antioxidant ability

\section{서 론}

산사과(Crataegi fructus)는 특유의 향긋한 냄새와 단맛과 신맛을 가지고 있는 장미과(Rosaceae)에 속한 산사나무 (Crataegus pinnatifida Bunge)의 성숙한 과실로, 우리나라 및 중국, 일본 전역에 자생하고 있으며 산사과의 수분 함량 은 $80.64 \%$ 이고 조단백 $0.26 \%$, 조지방 $0.30 \%$, 식이섬유소 $5.60 \%$, 포도당 및 과당은 각각 $5.02 \mathrm{mg} \%, 6.21 \mathrm{mg} \%$ 를 함유 하고 있으며 그 밖에 칼슘, 인, 망간, 아연, 철분, 구리 등을

*Corresponding author. E-mail : ksyoun@cu.ac.kr Phone : 82-53-850-3209, Fax : 82-53-850-3209

Received 4 November 2015; Revised 29 December 2015; Accepted 30 December 2015.

Copyright (c) The Korean Society of Food Preservation. All rights reserved.
함유하고 있고 특히 칼륨의 함량이 높다고 보고되어 있다 (1).

산사과의 약리 성분으로는 cyanidin-3-galactoside, pyrogallol, corosolic acid, hyperoside, protocatechuic acid, (-)-epicatechin, ursolic acid 등이 알려져 있다(2,3). 산사과의 phenolic compound의 대부분을 차지하는 것은 quercetin, hyricetin, gentisic acid, caffeic acid, catechin, salicylic acid 이며, 그 밖에 ferulic acid, naringin, chlorogenic acid, $\rho$ -coumaric acid도 미량 포함되어 있다(4). 산사과의 생리활 성으로는 항혈전, 항염증, 항산화, 간 손상 및 고지혈증 예방 하며, 산사과의 corosolic acid 성분은 체내에서의 소화 효소 의 작용 저해를 통해 혈당조절과 지질흡수를 저해하여 항당 뇨, 항 콜레스테롤에 대한 기능성을 가지고 있는 것으로 알려져 있다 $(5,6)$.

한편 산사과에 포함 되어 있는 약리 성분 중 pyrogallol, 
hyperoside 등은 체내에 활성 산소 제거 활성을 나타낸다. 활성 산소(reactive oxygen species, ROS)는 지질, 단백질, 핵산 등을 손상시키고 이러한 체내 조직의 손상은 당뇨병을 비롯하여 여러 만성질환의 가장 근본적인 요인으로 알려져 있다(7). 체내에서는 산화 작용이 일어남에 따라서 항상성 을 유지하려는 작용이 일어나며 이를 도와주는 항산화성분 이 함유된 식품에 대한 관심이 높아지고 있으며, 일반적으 로 페놀계 합성 항산화제로 널리 사용되고 있는 BHA (butylated hydroxyanisol)와 BHT(butylated hydroxy toluene) 는 그 효과와 경제성 그리고 안정성 때문에 많이 사용해 왔지만, 합성 식품첨가물의 일반적인 기피 현상뿐만 아니 라, 과량 섭취 시 위장점막, 폐, 신장, 순환계 등에 심각한 독성 작용을 일으키는 것으로 알려져 안전한 대체 항산화제 의 개발이 요구되었다 $(8,9)$.

일반 농가에서는 산사과를 천일 건조, 열풍 건조 하여 판매 하고 있으나 천일건조는 장기간의 건조과정 시에는 열화현상이 일어나 과육의 감소, 중량을 감소시키고 갈변 및 영양소의 파괴로 인한 품질 저하를 초래 할 수 있다. 열 풍건조의 경우는 신속하고 균일하게 건조가 이루어져 경제적이긴 하지만 수분손실에 기인된 수축현상, 빠른 건 조에 의한 재수화 시 낮은 복원율, 갈색화 반응으로 인한 색상변화, 조직감, 맛 및 영양가 저하 등의 문제점이 동반된 다(10). 위의 문제점을 개선하기 위해서 사용되어지는 동결 건조는 색조, 풍미, 복원성 등이 우수하며, 재료의 영양성분 의 파괴나 변형이 없어 고품질 농산물 가공에 적절하다고 할 수 있다(11).

따라서 본 연구에서는 양질의 건조 산사과를 생산하기 위하여 동결 건조와 열풍 건조에 따른 항산화 활성과 생리 활성의 차이를 비교하고자 하였다.

\section{재료 및 방법}

재 료

본 실험에서 사용된 산사과는 경북 영천 화산면에서 자 생하는 산사과로서 2014년 10월 수확하여 이물질을 제거 후 사용하였다. 열풍건조는 열풍건조기(IRD-250, Woori $\mathrm{Sci}$, Pocheon, Korea)를 사용 하여 $55^{\circ} \mathrm{C}$ 의 온도에서 72 시간 건조하였으며 동결건조는 Freeze dryer(FD SFDSM12, Samwon, Seoul,Korea)로 96시간 건조하였다. 건조물은 균 질기(Nihonseili, Kaisha Ltd, Tokyo, Japan)를 사용하여 40 mesh로 분쇄한 후 분말을 제조하여 $4^{\circ} \mathrm{C}$ 에서 보관하며 실험 에 사용하였으며, 실험에 사용된 모든 시약은 Sigma-Aldrich Co.(St. Louis, MO, USA)의 제품을 사용하였다.

\section{시료의 추출 및 수율 측정}

건조 방법에 따른 산사과의 추출방법은 분쇄시료 100 $\mathrm{g}$ 에 $1 \mathrm{~L}$ 의 증류수를 가한 후 상온교반추출방법으로 $25^{\circ} \mathrm{C}$ 의 실온에서 교반기(Wise Stir SMHS-3, DAIHAN Scientific Co., Seoul, Korea)를 이용하여 $250 \mathrm{rpm}$ 으로 24시간 추출하 였다, 각각의 추출물은 Whatman No. 1 여과지(Toyo Ltd., Tokyo, Japan)로 여과한 다음 rotary vaccum evaporator (rotary vacuum evaporator N-N series, Eyela, Tokyo, Japan) 로 감압농축한 후에 동결건조(freeze dryer, FD SFDSM12, Samwon, Seongnam, Korea) 하여 분말 시료를 제조하였으 며 $-50^{\circ} \mathrm{C}$ 에 보관하면서 실험에 사용하였다. 추출물의 수율 은 추출액을 동결건조 시켜 건물 중량을 구한 다음 추출액 조제에 사용한 원료 건물량에 대한 백분율로 나타내었다.

\section{색도 측정}

추출 분말의 색도는 표준백색판으로 보정된 chromameter (CR-300 Minolta, Tokyo, Japan)를 이용하여 측정하였다. Hunter scale에 의한 L(lightness), a(redness), b(yellowness) value를 측정하였다.

\section{총 폴리페놀 및 플라보노이드 함량}

폴리페놀 함량은 Dewanto 등의 방법(12)에 따라 시액 $100 \mu \mathrm{L}$ 에 $2 \%$ sodium carbonate $2 \mathrm{~mL}$ 과 $50 \%$ Folin-Ciacalteu reagent $100 \mu \mathrm{L}$ 을 가한 후 $720 \mathrm{~nm}$ 에서 흡광도를 측정하였으 며 gallic acid(Sigma-Aldrich Co.)의 검량선에 의하여 함량 을 산출하였다.

플라보노이드 함량은 Abdel-Hameed(13)의 방법에 따라 추출물 $100 \mathrm{~mL}$ 에 $5 \%$ sodium nitrite $0.15 \mathrm{~mL}$ 를 가한 후 $25^{\circ} \mathrm{C}$ 에서 6 분간 방치한 다음 $10 \%$ aluminium chloride 0.3 $\mathrm{mL}$ 를 가하여 $25^{\circ} \mathrm{C}$ 에서 5 분간 방치하였다. 다음 $1 \mathrm{~N} \mathrm{NaOH}$ $1 \mathrm{~mL}$ 를 가하고 교반한 다음 $510 \mathrm{~nm}$ 에서 흡광도를 측정하였 으며 rutin hydrate(Sigma-Aldrich Co.)의 검량선에 의하여 함량을 산출하였다.

\section{$\mathrm{DPPH}$ 및 $\mathrm{ABTS}+$ 라디칼 소거활성}

$\mathrm{DPPH}$ 라디칼 소거활성은 Blois의 방법(14)에 따라 시액 $0.2 \mathrm{~mL}$ 에 $0.4 \mathrm{mM}$ DPPH (1,1-diphenyl-2-picryl- hydrazyl)용 액 $0.8 \mathrm{~mL}$ 를 가하여 10 분간 방치 한 다음 $525 \mathrm{~nm}$ 에서 흡광 도를 측정하였으며 계산식, DPPH radical scavenging ability $(\%)=100-[(\mathrm{OD}$ of sample/OD of control $) \times 100]$ 에 의하 여 활성도를 산출하였다. ABTS 라디칼 소거활성은 Re 등 의 방법(15)에 따라 $7.4 \mathrm{mM}$ ABTS 2,2'-azino-bis 3-ethylbenzothiazoline-6-sulfonic acid) diammonium salt]와 $2.6 \mathrm{mM}$ potassium persulfate를 혼합하여 실온암소에서 24 시간 동안 방치하여 radical을 형성시킨 다음 실험 직전에 $\mathrm{ABTS}$ 용액을 $732 \mathrm{~nm}$ 에서 흡광도가 $0.7 \pm 0.03$ 이 되도록 phosphate buffer saline(PBS, pH 7.4)로 희석하여 사용하였 다. 희석된 용액 $950 \mu \mathrm{L}$ 에 추출물 $50 \mu \mathrm{L}$ 를 가하여 암소에서 10 분간 반응시킨 후 $732 \mathrm{~nm}$ 에서 흡광도를 측정하였으며 
계산식, ABTS radical scavenging ability $(\%)=100-[(\mathrm{OD}$ of sample/OD of control $\times \times 100]$ 에 의하여 활성을 산출하였다.

\section{아질산염 소거활성}

Kato 등의 방법(16)에 따라 $1 \mathrm{mM} \mathrm{NaNO}$ 용액 $1 \mathrm{~mL}$ 에 추출물 $1 \mathrm{~mL}$ 를 가하고 $0.1 \mathrm{~N} \mathrm{HCl}$ 과 $0.2 \mathrm{M}$ citrate buffer $(\mathrm{pH}$ $2.5)$ 를 가하여 총 부피를 $10 \mathrm{~mL}$ 로 조정하였다. 다음에 $37^{\circ} \mathrm{C}$ 에서 1 시간 반응시킨 후 $1 \mathrm{~mL}$ 를 취하여 $2 \%$ 초산용액 3 $\mathrm{mL}$ 와 $30 \%$ 초산용액으로 용해한 griess reagent $(1 \%$ sulfanilic acid: $1 \%$ naphthylamine $=1: 1) 0.4 \mathrm{~mL}$ 을 순차적으로 가한 후 실온에서 15 분간 방치, $520 \mathrm{~nm}$ 에서 흡광도를 측정 하였다. 대조구는 griess reagent를 사용하였으며 계산식, nitrite scavenging ability(\%)=100-[(OD of sample/OD of control) $\times 100]$ 에 의하여 산출하였다.

\section{$a$-Glucosidase 저해활성}

$\operatorname{Kim}$ 등의 방법(17)에 따라 추출물 $0.05 \mathrm{~mL}, 1$ uint $/ \mathrm{mL}$ a-glucosidase $0.05 \mathrm{~mL}$ 와 $200 \mathrm{mM}$ potassium phosphatebuffer $\left(\mathrm{pH} \mathrm{7.0)} 0.05 \mathrm{~mL}\right.$ 를 잘 혼합하여 $37^{\circ} \mathrm{C}$ 에서 10 분간 전처리하 였다. 다음에 $3 \mathrm{mM} \mathrm{\rho NPG}(\rho-$ nitrophenyl $a \mathrm{D}$-glucopyranoside) $0.1 \mathrm{~mL}$ 를 첨가하여 $37^{\circ} \mathrm{C}$ 에서 10 분간 반응시킨 후 $0.1 \mathrm{M}$ $\mathrm{Na}_{2} \mathrm{CO}_{3} 0.75 \mathrm{~mL}$ 로 반응을 정지시켜 $405 \mathrm{~nm}$ 에서 흡광도를 측정하였다. 이때, 활성 비교를 위하여 acarbose를 사용하였 다. 저해활성은 $a$-Glucosidase inhibition ability $(\%)=$ [1- $\left.\left(\mathrm{C}_{\mathrm{Abs}}-\mathrm{S}_{\mathrm{Abs}}\right) /\left(\mathrm{C}_{\mathrm{Abs}}-\mathrm{B}_{\mathrm{Abs}}\right)\right] \times 100$ : " $\mathrm{C}_{\mathrm{Abs}}$, 대조구 흡광도 $\mathrm{S}_{\mathrm{Abs}}$, 시 료흡광도 $\mathrm{B}_{\mathrm{Abs}}$, 시료 무첨가구의 흡광도”에 의하여 산출하 였다.

\section{$\mathrm{HMG}-\mathrm{Co} A$ reductase 저해활성 측정}

3-hydroxy-3-methylglutaryl-CoA(HMG-CoA) reductase 저해활성은 Kleinsek 등의 방법(18)을 변형하여 측정하였 다. 추출물 $40 \mu \mathrm{L}$, dimethyl sulfoxide $40 \mu \mathrm{L}$ 와 $0.5 \mu \mathrm{M}$ phosphate buffer(pH 7.0) $200 \mu \mathrm{L}$ 에 $20 \mathrm{mM}$ dithiothreitol 200 $\mu \mathrm{L}, 0.3 \mathrm{mM}$ $\beta$-NADPH $200 \mu \mathrm{L}$ 를 넣고 혼합하였다. 다음 $37^{\circ} \mathrm{C}$ 에서 3 분간 preincubation을 한 다음 $0.3 \mathrm{mM} \mathrm{HMG} \mathrm{CoA}$ $200 \mu \mathrm{L}$ 를 첨가하여 $37^{\circ} \mathrm{C}$ 에서 5 분간 반응시킨 후 $340 \mathrm{~nm}$ 에 서 흡광도 변화를 측정하였으며, 저해활성은 계산식, HMG-CoA reductase inhibitory ability $(\%)=\left[1-\left(\mathrm{C}_{\mathrm{Abs}}-\mathrm{S}_{\mathrm{Abs}}\right)\right.$ $\left./\left(\mathrm{C}_{\mathrm{Abs}}-\mathrm{B}_{\mathrm{Abs}}\right)\right] \times 100$ : " $\mathrm{C}_{\mathrm{Abs}}$; 대조구 흡광도, $\mathrm{S}_{\mathrm{Ab}}$; 시료 흡광도, $\mathrm{B}_{\mathrm{Abs}}$;시료 무첨가구의 흡광도”에 의하여 산출하였다.

\section{통계처리}

모든 실험은 3 회 반복으로 행하여 평균치와 표준편차로 나타내었고, 유의성 검증은 SPSS(Statistical Package for Social Science, 12, SPSS Inc., Chicago, IL, USA) Software package program을 이용하여 Duncan's mulitiple range test 및 t-test를 행하였다.

\section{결과 및 고찰}

\section{수율 및 색도}

건조 방법에 따른 산사과의 추출 수율, 색도는 Table 1 과 같다. 동결건조 산사과 추출물의 수율은 $61.70 \%$ 으로 나타 나 열풍건조 산사과 추출물의 $53.50 \%$ 보다 높은 수치를 나 타냈다. 이는 산사과 건조 과정에서 동결건조 과정 중 동결 시 산사과의 세포막의 파괴로 인하여 추출이 용이해졌기 때문이라고 사료 된다(19). 한편 색도에서는 밝기를 나타내 는 $\mathrm{L}$ 값과 황색도를 나타내는 $\mathrm{b}$ 값의 경우 열풍건조를 실시 한 산사과 추출물에서 높은 값을 나타내었으며, 적색도를 나타내는 a값은 동결건조 산사과 추출물이 높은 값을 보였 다. 이는 열풍건조 과정중의 높은 온도로 인한 갈변에 따른 결과로 판단되며 Yook 등(20)의 연구에서 열풍건조 포도 가공부산물이 동결건조 포도 가공부산물보다 $\mathrm{L}$ 값과 $\mathrm{b}$ 의 값이 높게 나타나 본 실험의 결과와 같은 경향을 나타내었 다.

Table 1. Yields and Hunter's color values of dried Haw prepared by different drying methods

\begin{tabular}{ccccc}
\hline \multirow{2}{*}{$\begin{array}{c}\text { Drying } \\
\text { Method }\end{array}$} & $\begin{array}{c}\text { Extraction } \\
\text { yields } \\
(\%)\end{array}$ & \multicolumn{3}{c}{ Hunter's color value } \\
\cline { 3 - 5 } & $($ (lightness) & a (redness) & b (yellowness) \\
\hline Freeze drying & $61.70^{\mathrm{a}}$ & $66.20 \pm 0.07^{1) \mathrm{a} 2)}$ & $11.70 \pm 0.02^{\mathrm{b}}$ & $22.47 \pm 0.08^{\mathrm{a}}$ \\
Hot air drying & $53.50^{\mathrm{b}}$ & $65.30 \pm 0.13^{\mathrm{b}}$ & $16.48 \pm 0.06^{\mathrm{a}}$ & $21.70 \pm 0.08^{\mathrm{b}}$ \\
\hline
\end{tabular}

${ }^{1)}$ Values are mean \pm standard deviation of triplicate determinations.

${ }^{2)}$ Different superscripts within a column $(a-b)$ indicate significant differences $(\mathrm{p}<0.05)$.

\section{총 폴리페놀 및 총 플라보노이드의 함량}

건조 방법에 따른 산사과 추출물의 총 폴리페놀 및 플라 보노이드 함량은 Table 2 와 같다. 산사과 추출물의 총 페놀 함량은 동결 건조 추출물에서 $15.78 \mathrm{mg} / \mathrm{g}$ 의 함량을 나태내 었고 열풍 건조 추출물은 $9.29 \mathrm{mg} / \mathrm{g}$ 의 함량을 나타내어 동결 건조 추출물에서 보다 높은 함량을 나타내었다. Nam 등 $(21)$ 의 산사과 연구에서는 열수추출물 $\left(80^{\circ} \mathrm{C}\right)$ 에서 20.02 $\mathrm{mg} / \mathrm{g}$ 의 함량을 나타내어 본 실험 결과에 비해 높은 값을 나타내었다, 이는 추출 시 추출 온도에 차이에 의한 것으로 사료된다.

총 플라보노이드의 함량은 동결 건조 추출물에서 26.46 $\mathrm{mg} / \mathrm{g}$ 함량을 보였고 열풍 건조 추출물에서는 $9.41 \mathrm{mg} / \mathrm{g}$ 의 함량을 나타내어, 총 폴리페놀의 함량과 같은 경향을 보였 다. 폴리페놀 화합물들은 우수한 항산화 활성을 가지는 것 으로 알려져 있으며, 이는 free radical을 안정화시키는 phenolic ring이 존재하기 때문으로 알려져 있다. 동결건조 산사과 추출물이 열풍건조 산사과 추출물보다 총 페놀, 플 라보노이드 함량이 높게 나타났다. 이는 건조과정 중 온도 에 따라 페놀성 화합물이 변형 되어 함량이 감소 된 것으로 생각된다. Chang 등(22)의 연구에서 또한 동결 건조한 포도 
Table 2. Total polyphenol and total flavonoid contents of dried Haw prepared by different drying methods

\begin{tabular}{ccc}
\hline Drying Method & $\begin{array}{c}\text { Polyphenols } \\
\left(\mathrm{mg} \mathrm{GAE}^{1} / \mathrm{g}\right)\end{array}$ & $\begin{array}{c}\text { Flavonoids } \\
\left(\mathrm{mg} \mathrm{RHE}^{2} / \mathrm{g}\right)\end{array}$ \\
\hline Freeze drying & $15.48 \pm 0.38^{3) \text { a } 4)}$ & $26.46 \pm 0.34^{\mathrm{a}}$ \\
Hot air drying & $9.29 \pm 0.50^{\mathrm{b}}$ & $9.41 \pm 0.26^{\mathrm{b}}$ \\
\hline
\end{tabular}

${ }^{1)} \mathrm{GAE}$, galic acid equivalents.

${ }^{2)}$ RHE, rutin hydrate equivalents.

${ }^{3)}$ Values are mean \pm standard deviation of triplicate determinations.

${ }^{2)}$ Different superscripts within a column $(\mathrm{a}-\mathrm{b})$ indicate significant differences $(\mathrm{p}<0.05)$

잎 추출물이 열풍건조한 포도잎 추출물보다 높은 폴리페놀 함량을 나타내어 본 실험과 같은 경향을 보였다.

\section{$\mathrm{DPPH}$ 및 $\mathrm{ABTS}$ 라디칼 소거활성}

건조 방법에 따른 산사과 추출물의 DPPH, ABTS 라디칼 소거활성을 측정한 결과는 Table 3 와 같다. DPPH, ABTS 라디칼 소거활성은 항산화활성을 나타내는 지표로 사용하 며, 일반적으로 페놀성물질의 함량과 연관성이 아주 높은 것으로 알려져 있다(23). 건조 방법에 따른 산사과의 DPPH 라디칼 소거활성은 $0.5 \mathrm{mg} / \mathrm{ml}$ 농도에서 동결건조 산사과 추출물이 $46.18 \%$, 열풍건조 산사과 추출물에서 $13.40 \%$ 로 동결건조 산사과 추출물의 활성이 높게 나타났다. Nam 등 (21)의 연구에서 산사과 추출물의 DPPH 라디칼 소거활성 이 $42.18 \%$ 로 나타나 본 연구의 동결건조 산사과 추출물과 유의한 활성을 나타내었다.

산사과 추출물의 $\mathrm{ABTS}$ 라디컬 소거활성은 동결건조 산 사과 추출물에서 $94.89 \%$ 의 수치를 보였고, 열풍건조 산사 과 추출물에서는 $42.64 \%$ 의 값을 나타내었다. 이는 DPPH 라디컬 소거활성과 동일한 경향을 나타 내었으며, Kang 등(24)의 연구에서 추출물의 라디칼 소거능이 페놀류에 기 인하여 항산화활성을 나타내어 총 폴리페놀 함량이 높을수 록 $\mathrm{DPPH}, \mathrm{ABTS}$ 라디칼 소거활성도 높다는 보고와 일치하 는 결과를 나타내었다.

Table 3. DPPH and ABTS radical scavenging abilities of dried Haw prepared by different drying methods

\begin{tabular}{ccc}
\hline Drying Method & $\begin{array}{c}\text { DPPH radical } \\
\text { scavenging ability } \\
(0.5 \mathrm{mg} / \mathrm{mL}, \%)\end{array}$ & $\begin{array}{c}\text { ABTS radical } \\
\text { Scavenging ability } \\
(0.5 \mathrm{mg} / \mathrm{mL}, \%)\end{array}$ \\
\hline Freeze drying & $46.18 \pm 0.16^{1 \mathrm{l}) 2}$ & $94.89 \pm 1.88^{\mathrm{a}}$ \\
Hot air drying & $13.40 \pm 0.29^{\mathrm{b}}$ & $42.64 \pm 1.90^{\mathrm{b}}$ \\
\hline
\end{tabular}

${ }^{1)}$ Values are mean \pm standard deviation of triplicate determinations.

${ }^{2}$ Different superscripts within a column $(\mathrm{a}-\mathrm{b})$ indicate significant differences $(\mathrm{p}<0.05)$.

\section{환원력 측정 및 아질산염 소거 활성}

건조방법에 따른 산사과 추출물의 환원력과 아질산염 소거활성은 Table 4에 나타내었다. 환원력은 reductone이 제공하는 수소원자가 자유라디칼 사슬을 분해함으로써 시
작되며 흡광도 수치 자체가 시료의 환원력을 나타내고, 높 은 환원력을 가지는 물질일수록 흡광도의 값이 높게 나타난 다(25). $5.0 \mathrm{mg} / \mathrm{mL}$ 의 같은 농도에서 동결건조 산사과 추출 물, 열풍건조 산사과 추출물의 환원력 $\mathrm{OD}$ 값을 확인 시 각각 $3.44,2.11$ 의 값을 나타내어 동결건조 산사과 추출물 에서 높은 환원력을 나타내는 것을 확인 할 수 있었다. Duan 등(26)의 보고에 의하면 $0.8 \mathrm{mg} / \mathrm{mL}$ 농도의 에탄올 산사과 추출물의 환원력 $\mathrm{OD}$ 값이 0.22 을 나타내어 본 실험보다 낮은 값을 나타내었는데 이는 시료의 농도가 증가할수록 환원력 또한 증가하고 추출하는 용매에 따라 환원력의 차이 는 크기 때문이라 판단된다(27).

$\mathrm{NO}_{2}$ 는 식품 첨가 물질로 산성 조건 하에서 2 급 아민 등의 아민류와 반응하여 발암 물질인 nitrosamine을 형성하 고, 일정량 이상 섭취하게 되면 각종 중독을 일으키는 것으 로 알려져 있다(25). $5.0 \mathrm{mg} / \mathrm{mL}$ 의 농도에서 동결건조 산사 과 추출물, 열풍건조 산사과 추출물의 아질산염 소거활성 은 각각 $88.00 \%, 55.13 \%$ 의 값을 나타내는 것을 확인 할 수 있었다. 동결건조 산사과추출물의 아질산염 소거 활성 이 열풍건조 산사과 추출물 보다 높은 활성을 나타내는 것을 볼 수 있었으며, 이는 폴리페놀과 플라보노이드 화합 물은 종류에 따라 차이는 있으나 phenol계 유도체들이 nitroso화합물의 생성을 억제 한다는 실험 결과(28)와 비교 하였을 때 건조 방법에 따라서 산사과 추출물이 가지는 페놀성 화합물의 함량의 차이에 따른 결과라 판단된다.

Table 4. Reducing power and nitrite scavenging ability of dried Haw prepared by different drying methods

\begin{tabular}{ccc}
\hline Drying Method & $\begin{array}{c}\text { Reducing power } \\
\left(5.0 \mathrm{mg} / \mathrm{mL}, \mathrm{OD}_{700}\right)\end{array}$ & $\begin{array}{c}\text { Nitrite-scavenging abilities } \\
(5.0 \mathrm{mg} / \mathrm{mL}, \%)\end{array}$ \\
\hline Freeze drying & $3.44 \pm 0.00^{1 \mathrm{a} 2)}$ & $88.00 \pm 2.34^{\mathrm{a}}$ \\
Hot air drying & $2.11 \pm 0.01^{\mathrm{b}}$ & $55.13 \pm 0.31^{\mathrm{b}}$ \\
\hline
\end{tabular}

${ }^{1)}$ Values are mean \pm standard deviation of triplicate determinations.

${ }^{2)}$ Different superscripts within a column $(a-b)$ indicate significant differences $(p<0.05)$.

a-Glucosidase 및 HMG-CoA reductase 저해활성

건조방법을 달리한 산사과 추출물의 a-glucosidase, HMG-CoA reductase 저해활성을 측정한 결과는 Table 5와 같다. 일반적으로 a-glucosidase는 소장 상피세포의 미세 융모막(brush bordermembrane)에 존재하는 효소로서, 소장 에서 음식물 중의 전분을 포도당과 같은 당으로 분해하여 흡수시킨다. a-glucosidase 저해제는 이당류의 분해효소를 가역적으로 억제하여 탄수화물의 흡수를 지연시키는 역할 을 하며, 소장전체에 포도당이 흡수되어 식후 혈당 상승을 완만하게 한다(29). $0.01 \mathrm{mg} / \mathrm{mL}$ 의 농도에서 a-glucosidase 저해활성을 측정한 결과는 동결건조 산사과 추출물, 열풍 건조 산사과 추출물 각각 $97.38 \%, 24.96 \%$ 의 값을 나타내었 으며, 양성대조군인 $0.5 \mathrm{mg} / \mathrm{mL}$ 의 acarbose와 비교하였을 
시 산사과 추출물이 낮은 농도 임에도 불구하고, 높은 활성 값을 나타내었다, 이는 Nam 등(20)의 실험 중 산사과 에탄 올 추출물이 acarbose보다 높은 저해 활성을 나타내었다는 연구와 동일한 결과를 보였다. 또한 동결건조 산사과 추출 물이 열풍건조 산사과 추출물에 비해 월등히 높은 값을 나타내는 것을 볼 수 있었으며, 이는 Xu 등(30)은 토후박 추출물에서 총 페놀 함량과 DPPH 라디칼 소거활성이 높을 수록 a-glucosidase의 활성이 높다고 보고하는 것과 일치하 는 값을 나타내었다.

HMG-CoA reductase는 콜레스테롤 생합성 단계에서 작 용하는 rate-limiting enzyme으로써 스테롤이나 이소프레노 이드계 화합물의 생합성 경로의 중간단계인 mevalonic acid 의 합성을 매개하는 역할을 한다. 따라서 HMG-CoA reductase 활성이 저하되면 LDL-receptor의 활성이 증가되 어 혈중 콜레스테롤 농도를 감소시킨다고 보고되고 있다 (31). 건조방법에 따른 산사과 추출물의 HMG-CoA reductase 저해활성을 측정한 결과 동결건조 산사과 추출물, 열풍건조 산사과 추출물 각각 $74.67 \%, 72.11 \%$ 의 값을 나타 내었다. 특히 HMG-CoA reductase 저해활성 실험에서는 열 풍건조 산사과 추출물의 활성이 동결건조 산사과 추출물 보다 높은 값을 보여 다른 실험의 결과와 상반되어 졌는데 이는 HMG-CoA reductase 저해활성에 관여하는 statin물질 (33)이 $55^{\circ} \mathrm{C}$ 의 건조 온도에서 안정함을 나타낸 것으로 사료 된다. 산사과 추출물은 양성대조군인 $0.1 \mathrm{mg} / \mathrm{mL}$ 의 농도 ascorbic acid의 HMG-CoA reductase 저해활성 $95.01 \%$ 의 수준에는 미치지 못하였으나 전체적으로 높은 저해 활성을 보여 천연 저해제 후보 물질로써의 가능성을 나타내었다. $\operatorname{Kim}$ 등(32)의 자생 산사과의 고지혈증 개선효과 실험에서 나타난 산사과 추출물의 효능과 유의하다고 판단된다.

Table 5. a-Glucosidase and HMG-CoA reductase inhibition activities of dried Haw prepared by different drying methods

\begin{tabular}{|c|c|c|c|c|}
\hline \multirow[b]{2}{*}{ Measurement ${ }^{1)}$} & \multirow{2}{*}{$\begin{array}{l}\text { Freeze } \\
\text { drying }\end{array}$} & \multirow{2}{*}{$\begin{array}{c}\text { Hot air } \\
\text { drying }\end{array}$} & \multicolumn{2}{|c|}{ Positive control } \\
\hline & & & Acarbose & $\begin{array}{l}\text { Ascorbic } \\
\text { acid }\end{array}$ \\
\hline $\begin{array}{c}\text { a-Glucosidase } \\
\text { inhibitory ability (\%) }\end{array}$ & $97.38 \pm 0.09^{2) a 3)}$ & $24.96 \pm 1.12^{\mathrm{b}}$ & $29.01 \pm 0.12$ & - \\
\hline $\begin{array}{l}\text { HMG-CoA reductase } \\
\text { inhibitory ability (\%) }\end{array}$ & $72.11 \pm 0.47^{b}$ & $74.67 \pm 0.90^{\mathrm{a}}$ & - & $87.36 \pm 0.26$ \\
\hline
\end{tabular}

\section{요 약}

건조 방법을 달리하여 건조한 산사과 추출물의 항산화 활성 및 생리활성의 특성을 비교하였다. 건조 산사과의 추
출 수율은 동결건조 추출물이 $(61.70 \%)$ 열풍건조 추추물 (53.50\%) 보다 높은 값을 나타내었으며, 총 폴리페놀과 플 라보노이드 함량에서도 동결건조 산사과 추출물이 열풍건 조 추출물에 비하여 높은 값을 보였다. 항산화 활성 또한 동결 건조 산사과 추출물에서 열풍 건조 산사과 추출물보다 높은 활성을 나타내었고, 특히 DPPH 라디칼 소거능에서 동결건조 산사과 추출물이 열 풍건조 산사과 추출물 보다 3 배 넘는 활성을 나타내었다. a-Glucosidase inhibitory ability에서는 동결건조 산사과가 열풍건조 산사과, 양성대 조군인 acarbose보다 높은 활성을 나타내었으며, HMG-CoA reductase 저해활성에서는 동결, 열풍 산사과 추 출물이 전체적으로 높은 저해 활성을 나타내어 콜레스테롤 개선효과에 대한 가능성을 나타내었다. 이러한 결과를 종 합해 볼 때 동결건조 방법을 이용하는 것이 산사과의 건조 효율 증대와 품질손상을 억제 할 수 있는 건조 방법으로 판단된다.

\section{References}

1. Chon JW, Park SJ, Han JH, Park SH (2005) Study of Crataegi fructus for medicinal foods applications-nutrition composition and scheme for foods. Korean J Oriental Physiology Pathology, 19, 1220-1224

2. Kim JS, Lee GD, Kwon JH, Yoon HS (1993) Identification of phenolic antioxidative components in Crataegus pinnatifida BUNGE. J Korean Agric Chem Soc, 36, 154-157

3. Liu P, Yang B, Kallio H (2010) Characterization of phenolic compounds in Chinese hawthorn (Crataegus pinnatifida Bge. var. major) fruit by high performance liquid chromatography-electrospray ionization mass spectrometry. Food Chem, 121, 1188-1197

4. Ryu HY, Ahn SM, Kim JS, Jung IC, Sohn HY (2010) Antimicrobial activity of fruit of Crataegus pinnatifida BUNGE against multidrug resistant pathogenic Pseudomonas aeruginosa and Candida sp. Korean J Microbiol Biotechnol, 38, 77-83

5. Kwon SH, Kim JB (2010) Effects of Crataegii Fructuson the diet-induced hyperlipidemia in rats. Korean J Oriental Physiology Pathology, 24, 67-73

6. Ryu HY, Kim YK, Kwun IS, Kwon CS, Jin IN, Sohn HY (2007) Thrombin inhibition activity of fructus extract of Crataegus pinnatifida BUNGE. J Life Science, 17, 535-539

7. Seifried HE, Anderson DE, Fisher EI, Milner JA (2007) A review of the interaction among dietary antioxidants 
and reactive oxygen species. J Nutr Biochem, 18, 567-579

8. Branen AL (1975) Toxicology and biochemistry of butylated hydroxyanisol and butylated hydroxytoluene.

J Am Oil Chem Soc, 52, 59-63

9. Choe SY, Yang KH (1982) Toxicological studies of antioxidants, butylated hydroxytoluene (BHT) and butylated hydroxyanisol (BHA). Korean J Food Sci Technol, 14, 283-288

10. Holdsworth SD (1971) Dehydration of food products. J Food Technol, 6, 331-370

11. Kim JW, Lee SH, No HK, Hong JH, Park CS, Youn KS (2013) Effects of pretreatment and drying methods on quality and antioxidant activities of dried jujube (Zizyphus jujuba) fruit. J Korean Soc Food Sci Nutr, 42, 1242-1248

12. Dewanto V, Wu X, Adom KK, Liu RH (2002) Thermal processing enhances the nutritional value of tomatoes by increasing total antioxidant activity. J Agric Food Chem, 50, 3010-3014

13. Abdel-Hameed ES (2009) Total phenolic contents and free radical scavenging activity of certain Egyptian Ficus species leaf samples. Food Chem, 114, 1271-1277

14. Blois MS (1958) Antioxidant determination by the use of a stable free radical. Nature, 181, 1199-1200

15. Re R, Pellegrini N, Proteggente A, Pannala A, Yang M, Rice-Evans C (1999) Antioxidant activity applying an improved ABTS radical cation decolorization assay. Free Radic Biol Med, 26, 1231-1237

16. Kato H, Lee IE, Chuyen NV, Kim SB, Hayase F (1987) Inhibition of nitrosamine formation by nondialyzable melanoidins. Agric Biol Chem, 51, 1333-1338

17. Kim KY, Nam KA, Kurihara H, Kim SM (2008) Potent a-Glucosidase inhibitors purified from the red alga Grateloupia elliptica. Phytochemistry, 69, 2820-2825

18. Kleinsek DA, Ranganathan S, Porter JW (1977) Purification of 3-hydroxy-3- methylglutaryl-coenzyme A reductase from rat liver. Proc Natl Acad Sci, 74, 1431-1435

19. Kim MA, Duan Yishan, Seong JH, Chung HS, Kim HS (2014) Antioxidative activity of feral Haw (Crataegus pinnatifida BUNGE) seed extracts using various solvents. Korean J Food Cook Sci, 30, 33-40

20. Yook HS, Kim KH, Jang SA (2010) Quality characteristics of grape pomace with different drying methods. J Korean Soc Food Sci Nutr, 39, 1353-1358

21. Nam SM, Kang IJ, Shin MH (2015) Anti-diabetic and anti-oxidative activities of extracts from Crataegus pinnatifida. J East Asian Soc Dietary Life, 25, 270-277

22. Chang SW, Shin NS, Song JH, Kim HJ, Lee KY, Rho YT (2009) Production of high-level polyphenol powders from young grape leaves. Korean J Food Preserv, 16, 714-718

23. Hong MJ, Lee GD, Kim HK, Kwon JH (1998) Change in functional and sensory properties of Chicory roots induced by roasting processes. Korean J Food Sci Technol, 30, 413-418

24. Kang MH, Park CG, Cha MS, Seong NS, Chung HK, Lee JB (2001) Component characteristics of each extract prepared by different extract methods from by products of glycyrrhizia uralensis. J Korean Soc Food Sci Nutr, 30, 138-142

25. Jeong $\mathrm{CH}$, Shim $\mathrm{KH}$ (2006) Chemical composition and antioxidative activities of Platycodon grandiflorum leaves and stems. J Korean Soc Food Sci Nutr, 35, 511-515

26. Duan Yishan, Kim MA, Seong JH, Lee YG, Kim DS, Chung HS, Kim HS (2014) Antioxidative activities of various solvent extracts from Haw (Crataegus pinnatifida BUNGE). Korean J Food Preserv, 21, 246-253

27. Ju JC, Shin JH, Lee SJ, Cho HS, Sung NJ (2006) Antioxidative activity of hot water extracts from medicinal plants. J Korean Soc Food Sci Nutr, 35, 7-14

28. Takashi Y, Yamamoto M, Tamura A (1978) The effects of some polyphenols on nitrosation of diethylamine. $\mathrm{J}$ Food Hyg Soc, 19, 224-229

29. Kim HY, Lim SH, Park YH, Ham HJ, Lee KJ, Park DS, Kim KH, Kim S (2011) Screening of a-amylase, a-glucosidase and lipase inhibitory activity with Gangwon-do wild plants extracts. J Korean Soc Food Sci Nutr, 40, 308-315

30. $\mathrm{Xu} \mathrm{ML}, \mathrm{Hu} \mathrm{JH}$, Wang L, Kim HS, Jin CW, Cho DH (2010) Antioxidant and anti-diabetes activity of extracts from Machilus thunbergii S. et Z. Korean J Medicinal Crop Sci, 18, 34-39

31. Lee SG, Kim HJ, Yu MH, Lee EJ, Lee SP, Lee IS (2010) Cholesterol improvement synergistic effects of fermented soybean grits caused by added with Mung bean in vitro. J Korean Soc Food Sci Nutr, 39, 947-952

32. Kim HS, Kim MA, Jang SH (2014) Improvement effect of hyperlipidemia by wild Haw (Crataegus pinnatifida BUNGE). J Env Sci Intern, 23, 787-792

33. Choi BC (2009) Analysis on statins for the treatment of bone fracture. Yakhak Hoeji, 53, 206-216 